\title{
Morphology and head morphometric characters of sperm in Thai native crossbred stallions

\author{
Kanittha Phetudomsinsuk ${ }^{\dagger 1,2}$, Kaitkanoke Sirinarumitr*†1, Aree Laikul ${ }^{\dagger 1}$ and \\ Anuchai Pinyopummin ${ }^{\dagger 1}$
}

\author{
Address: ${ }^{1}$ Faculty of Veterinary Medicine, Kasetsart University, Kamphaeng Saen Campus, Nakhon Pathom 73140 , Thailand and ${ }^{2}$ Center for \\ Agricultural Biotechnology, Kasetsart University, Kamphaeng Saen Campus, Nakhon Pathom 73140, Thailand \\ Email: Kanittha Phetudomsinsuk - fvetktp@ku.ac.th; Kaitkanoke Sirinarumitr* - fvetkns@ku.ac.th; Aree Laikul - fvetarl@ku.ac.th; \\ Anuchai Pinyopummin - fvetacp@ku.ac.th \\ * Corresponding author †Equal contributors
}

Published: 22 October 2008

Acta Veterinaria Scandinavica 2008, 50:4I doi:10.1I86/I75I-0|47-50-4I

This article is available from: http://www.actavetscand.com/content/50/I/4I

(C) 2008 Phetudomsinsuk et al; licensee BioMed Central Ltd.

This is an Open Access article distributed under the terms of the Creative Commons Attribution License (http://creativecommons.org/licenses/by/2.0), which permits unrestricted use, distribution, and reproduction in any medium, provided the original work is properly cited.
Received: 4 July 2008

Accepted: 22 October 2008

\begin{abstract}
Background: One of the semen quality parameters use to determine fertility is the percentage of sperm that express normal morphology. Sperm head morphometry is also correlated with fertility. The objectives of this study were I) to investigate the sperm morphology and normal sperm head morphometry of Thai native crossbred stallions, and 2) to compare our results with the characteristics of proven fertile sperm from purebred stallions.

Methods: Semen samples were collected monthly from nine stallions, of which five were Thai native crossbred (T) and four were purebred of proven fertility (F: FI was a Standard-bred; F2 was a Warmblood; F3 and F4 were Thoroughbreds). All the animals were aged between 5 and 12 years. Sperm morphological examination was performed using formaldehyde-fixed samples under phase-contrast microscopy (1000x). Normal sperm head morphometry characteristics were measured by ComputerAssisted Semen Analysis (Hamilton Thorne, USA.) after applying the Harris' haematoxylin staining technique.

Results: The percentages of morphologically normal and abnormal sperm varied among individual stallions in both the $\mathrm{T}$ and $\mathrm{F}$ groups. The mean percentage of morphologically normal sperm was not significantly different $(P>0.05)$ between $T$ and $F$ stallions (mean $\pm S E, 49.7 \pm 1.3$ and 48.I \pm 2.8 , respectively). A comparison between the $T$ and $F$ sperm heads revealed that all the dimensional parameters were significantly different $(P<0.05)$. The coefficients of within-animal variation $(C V s)$ ranged from 2.6 (shape factor I) to 7.5 (elongation) and 2.9 (shape factor I) to 8.I (elongation) in $T$ and $F$, respectively. In the case of the $\mathrm{T}$ group, those sperm head parameters that featured a low within-animal CV and a high between-animal CV were perimeter $(2.9,19.1)$, shape factor I $(2.6,25.8)$ and shape factor $3(3.8,32.0)$. In the case of the F group, only shape factor I $(2.9,26 . I)$ featured such characteristics.
\end{abstract}

Conclusion: We found variability in the percentage of morphologically normal and abnormal sperm, as well as in sperm head dimensions among Thai native crossbred stallions, and these results were similar to those of purebred stallions. Our findings demonstrate that the heads of the T sperm specimens were larger and rounder than that of the F sperm. Perimeter, shape factor I and shape factor 3 could be used as parameters for the identification of individual $\mathrm{T}$ stallions based on a sperm sample. 


\section{Background}

Recent studies have shown that male fertility does not only depend on the absolute number of viable, motile, morphologically normal sperm that can be inseminated in a female. Rather, a more important parameter appears to be the functional competence of sperm cells - since this cannot be evaluated using a single variable, researchers have proposed that semen samples should be subjected to multi-parametric analysis [1-3]. However, gross morphological classification of the sperm in order to assess male fertility can be used as a practical screening tool and is already a part of the breeding soundness examination (BSE) that is used in Thailand for all domestic species, including horses [4]. An ejaculation containing a minimum of one billion morphologically normal, progressively motile sperm specimens in each of two ejaculates sampled at any time during the year is the guideline for satisfactory stallion BSE as codified by the Society for Theriogenology $[4,5]$. Under light microscopy, a significant increase in the morphological abnormality of sperm samples was observed in stallions that were either infertile or of dubious fertility $[6,7]$. The average stallion had approximately 50\% morphologically normal sperm, but some stallions with less than $40 \%$ morphologically normal specimens may achieve acceptable pregnancy rates if a minimum threshold number of normal sperm are present [8].

Sperm head morphometry assessed by Computer-Assisted Semen Analysis (CASA) has been shown to correlate with fertility in various species including horses [9], boar $[10,11]$, Iberian red deer [12], and canines [13]. Substantial differences in sperm head shape and size were found within breeds in stallions [14,15], rams [16], bulls [17], alpacas [18], red deer [19], and boar [20]. Between-breed differences were identified in stallions [14], canines [21], bulls [17], boar [22], and buffalo [23]. Such variability could be, in part, due to genotypic effects [24].

There are two main horse groups in Thailand: purebred and Thai native crossbred horses. The country has a total population of 2,327 horses (Statistics of Livestock in Thailand: 2006, Department of Livestock Development, Ministry of Agriculture and Cooperatives). Purebred horse strains include Arabians, Standard-bred, Thoroughbred and Warm-blood, all of which were originally introduced to Thailand by importation. The Thai native crossbred horse is a pony horse that may have originated from a Burmese breed [25]. However, the scientific origin of the breed remains obscure. Nowadays, this native breed is generally used in religious ceremonies, for recreational activities, and occasionally for transportation in highland areas. Natural breeding with stallions is commonly performed to increase horse numbers. However, applications of reproductive technology in Thai native crossbred horses such as chilled semen or frozen semen are not available. Artificial insemination with chilled or frozenthaw semen may be an important method for increasing population numbers of this horse, and a detailed study of its semen characteristics was therefore considered necessary.

The study aims to 1) investigate the sperm morphology and normal sperm head morphometry of Thai native crossbred animals, and 2) compare the obtained results with the characteristics of purebred stallion sperm of proven fertility.

\section{Materials and methods Chemicals}

All chemicals in this study were purchased from Sigma Chemical Company (Sigma, St Louis, MO, USA) unless otherwise stated.

\section{Animals and Semen Collection}

The investigation was performed on nine clinically healthy stallions, of which five were Thai native crossbreds (T: T1 - T5) and four were purebred animals of proven fertility (F: F1 was a Standard-bred; F2 was a Warm-blood; F3 and F4 were Thoroughbreds). All were aged between 5 and 12 years. Semen was collected using a Missouri-type artificial vagina on a monthly basis over the period January through June 2007 for a total of six ejaculates per stallion. Multiple semen parameters were routinely determined including volume, color, consistency, motility, progressive motility, and concentration. All the ejaculates were analyzed to evaluate sperm morphology. In the case of sperm head morphometry assessment, we used only the final four ejaculates in our analysis.

\section{Sperm Morphology Examination}

Sperm morphology was studied in wet preparations comprising samples fixed in formal-saline [26] under a phasecontrast microscope (Olympus, Tokyo, Japan) at a magnification of $1000 \times$. A total of 200 sperm in each ejaculate were examined for morphological abnormalities according to the criteria defined by Dowsett et al. [27]. Certain findings of abnormalities in the $\mathrm{T}$ sperm group were further examined under eosin/nigrosin staining or using scanning electron microscopy.

\section{Sperm Head Morphometry Measurements}

A $200 \mu \mathrm{l}$ semen sample was washed and diluted with Dulbecco's phosphate-buffered saline (DPBS) to a concentration of approximately $100 \times 10^{6} \mathrm{sperm} / \mathrm{ml}$. Smears were prepared by taking a $7 \mu \mathrm{l}$ drop of the diluted sperm, smearing it across a clean glass slide, and air-drying overnight. 


\section{Staining procedures}

The sample slides were stained for 40 min with Harris haematoxylin technique [28], and were permanently mounted before the sperm head was measured.

\section{Head measurement}

The slide was loaded into an IVOS version 12.3 microscopy system (Hamilton Thorne Research, Beverly, MA, USA) with the aid of a computer-controlled specimen stage. The images were evaluated using commercial morphology software (Oval Metrix Version 4.18). Recognition of sperm and the rejection of other cells were performed at an accuracy consistent with the hardware and software specifications. The analysis software settings were minimum contrast 15 , minimum size $1 \mu \mathrm{m}^{2}$, erosion level 7.0, camera gain 50 , camera contrast 180 , and scale $0.147 \mu \mathrm{m} /$ px. The manufacturer-recommended objective magnification for equine sperm microscopy was 60×. 200 morphologically normal sperm heads were acquired in each test, and consequently a total of 800 sperm were analyzed for each animal. The software reported five sperm head features, namely length $(\mathrm{L} ; \mu \mathrm{m})$, width $(\mathrm{W} ; \mu \mathrm{m})$, elongation [(width/length $) \times 100 ; \%]$, perimeter $(\mathrm{P} ; \mu \mathrm{m})$ and head area $\left(\mathrm{A} ; \mu \mathrm{m}^{2}\right)$. In addition, the software calculated four non-dimensional derived parameters, namely ellipticity $(\mathrm{e})=(\mathrm{L}-\mathrm{W}) /(\mathrm{L}+\mathrm{W})$; shape factor $1(\mathrm{Sf} 1$; rugosity $)=4 \pi \mathrm{A} /$ $\mathrm{P}^{2}$; shape factor $2(\mathrm{Sf} 2)=\mathrm{Sf} 1 \times(\mathrm{L} / \mathrm{W})$ and shape factor 3 $(\mathrm{Sf} 3$; regularity) $=\pi \mathrm{L} / \mathrm{W} / 4 \mathrm{~A}[18]$.

\section{Statistical Analyses}

Statistical comparisons were made using the SPSS/PC+ statistics package (version 12.0 for Windows, SPSS Inc, Chicago, IL, USA). For each morphometric parameter, the normality and homogeneity of the data's variance distribution were assessed using the Kolmogorov-Smirnov and Levene's tests. One-way ANOVA producing significant Fvalues was followed by an LSD test for comparisons between multiple animals. An independent-samples T test was used for comparisons between groups of animals. All data given were summarized as mean \pm standard error of the mean (SE). The coefficient of variation (CV) was calculated for both within-animal and between-animal groups [18].

\section{Results}

The color and aspect of the ejaculates ranged from milky white to opalescent white. For T stallions, the mean \pm SE of gel free-volume, motility, progressive motility, living sperm and concentration were $44.0 \pm 2.1 \mathrm{ml}, 77.8 \pm 1.3 \%$, $55.4 \pm 1.3 \%, 75.5 \pm 1.3 \%, 309.0 \pm 30.7 \times 10^{6}$ sperm, respectively. For the F group, the mean \pm SE of gel free-volume, motility, progressive motility, live sperm and concentration were $47.0 \pm 3.2 \mathrm{ml}, 73.0 \pm 2.0 \%, 46.8 \pm 1.7 \%$, $73.9 \pm 1.6 \%, 374.5 \pm 28.4 \times 10^{6}$ sperm, respectively.

\section{Sperm Morphology}

Morphology measurements from the individual ejaculate samples of $\mathrm{T}$ and $\mathrm{F}$ stallions are presented in Table 1. Sperm morphology varied among stallions with respect to all parameters. On average, the $\mathrm{T}$ and $\mathrm{F}$ groups were not significantly different $(\mathrm{P}>0.05)$ in respect of percentage of sperm that exhibited normal morphology. However, the percentages of each type of morphologically abnormal sperm were significantly different $(P<0.05)$. Overall, the most common abnormality in both $\mathrm{T}$ and $\mathrm{F}$ stallions comprised sperm that had an abnormal midpiece. Morphologically normal and abnormal sperm from the $\mathrm{T}$ group are shown in Figure 1 (detected by scanning electron microscopy) and Figure 2 (stained with eosin/nigrosin and detected by light microscopy).

The mean of numbers of morphologically normal sperm with progressive motility in each ejaculate ranged from $1.83 \pm 0.37$ to $4.68 \pm 0.47$ billion and $3.18 \pm 0.53$ to 5.41 \pm 1.61 billion in $\mathrm{T}$ and $\mathrm{F}$ stallions, respectively.

\section{Sperm Head Morphometry}

Parameters for the morphometric characteristics of normal sperm heads are summarized in Table 2. There were differences $(\mathrm{P}<0.05)$ between individual stallions in both $\mathrm{T}$ and $\mathrm{F}$. Comparisons between the mean values of each characteristic of normal $\mathrm{T}$ and $\mathrm{F}$ sperm heads showed that the length, elongation, perimeter and area values were higher for $\mathrm{T}$ than for $\mathrm{F}(\mathrm{P}<0.05)$. Thus, this indicated that the sperm heads of $\mathrm{T}$ stallions were rounder and larger than those of F stallions were.

The percentage CV values of normal sperm head morphometric characteristics were quite low, ranging from 3.3 (shape factor 1 and perimeter) to 8.5 (elongation) and 3.4 (shape factor 1) to 8.8 (elongation) in $\mathrm{T}$ and $\mathrm{F}$ stallions, respectively (Table 2 ). Within-stallion group analysis indicated that the $\mathrm{CV}$ values in both $\mathrm{T}$ and $\mathrm{F}$ sperm were also low (Table 3), while analysis of the between-animal groups found that the percentage CVs were quite high for perimeter (19.2), area (19.8), length (28.9), shape factor 1 (25.8) and shape factor 3 (32.0) for T stallions, but were only high in the case of shape factor 1 (26.1) for F sperm. The sperm head parameters with a low within-animal CV and a high between-animal CV were perimeter $(2.9,19.1)$, shape factor $1(2.6,25.8)$ and shape factor $3(3.8,32.0)$ for $\mathrm{T}$. The latter characteristics were observed only in the shape factor 1 variable $(2.9,26.1)$ for $F$ sperm.

\section{Discussion}

The percentages of each type of sperm morphology were variable across both $\mathrm{T}$ stallions and $\mathrm{F}$ stallions. Inter-animal variation was found both within breeds [29] and between breeds [29-31]. The overall percentage of morphologically normal sperm was $49.7 \%$ and $48.1 \%$ for $\mathrm{T}$ 

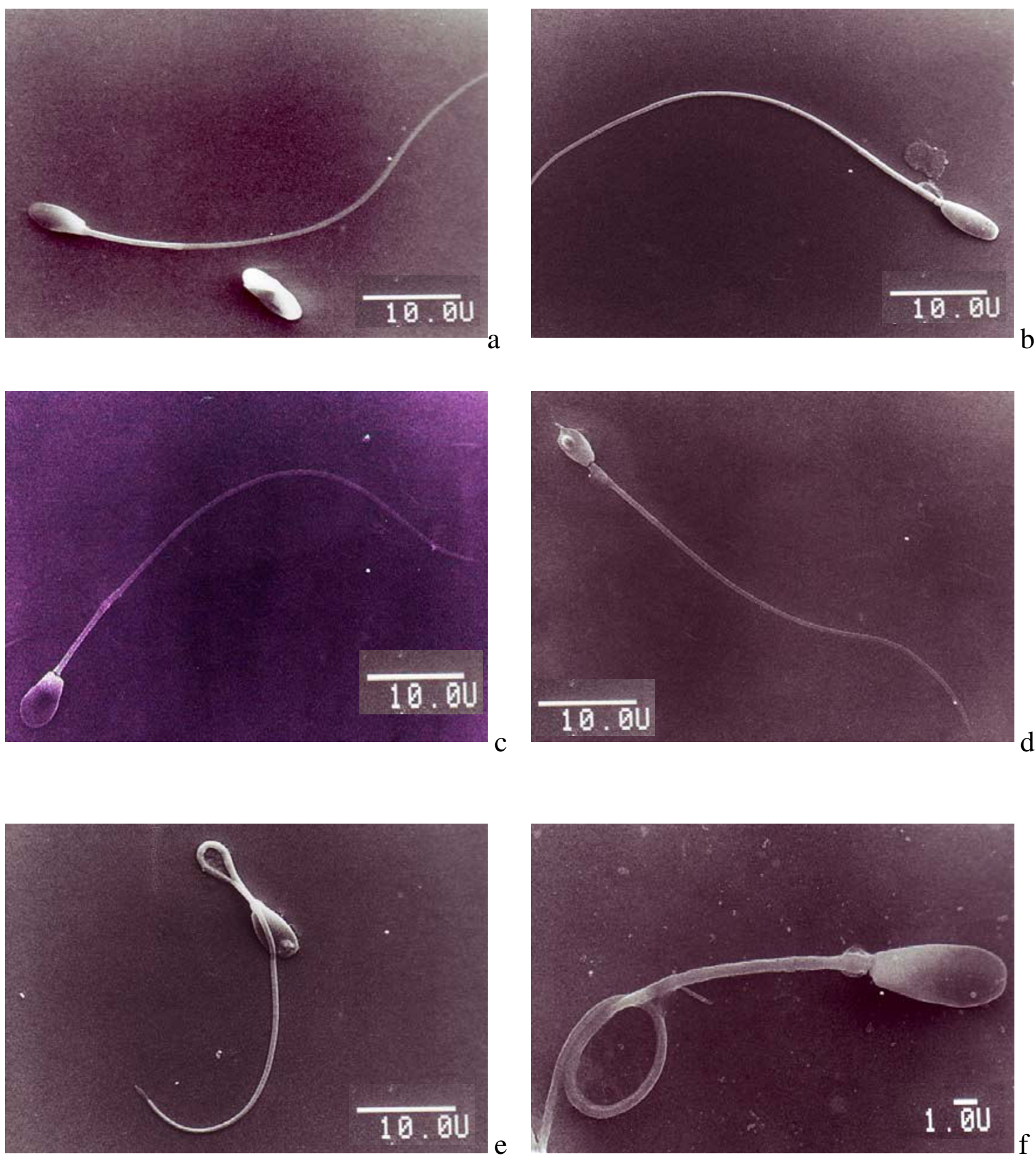

\section{Figure I}

Scanning electron microscopy of Thai native crossbreed stallion sperm; a - normal sperm (top) and loose narrow head (below); $b$ - narrow head with proximal cytoplasmic droplet; $c$ - round head; $d$ - acrosomal defect; $e$ - acrosomal defect and bent tail and $f-$ proximal cytoplasmic droplet with coiled tail $(a-e-2000 x$, bar $=10$ micrometers; $f-3600 x$, bar $=1$ micrometers). 

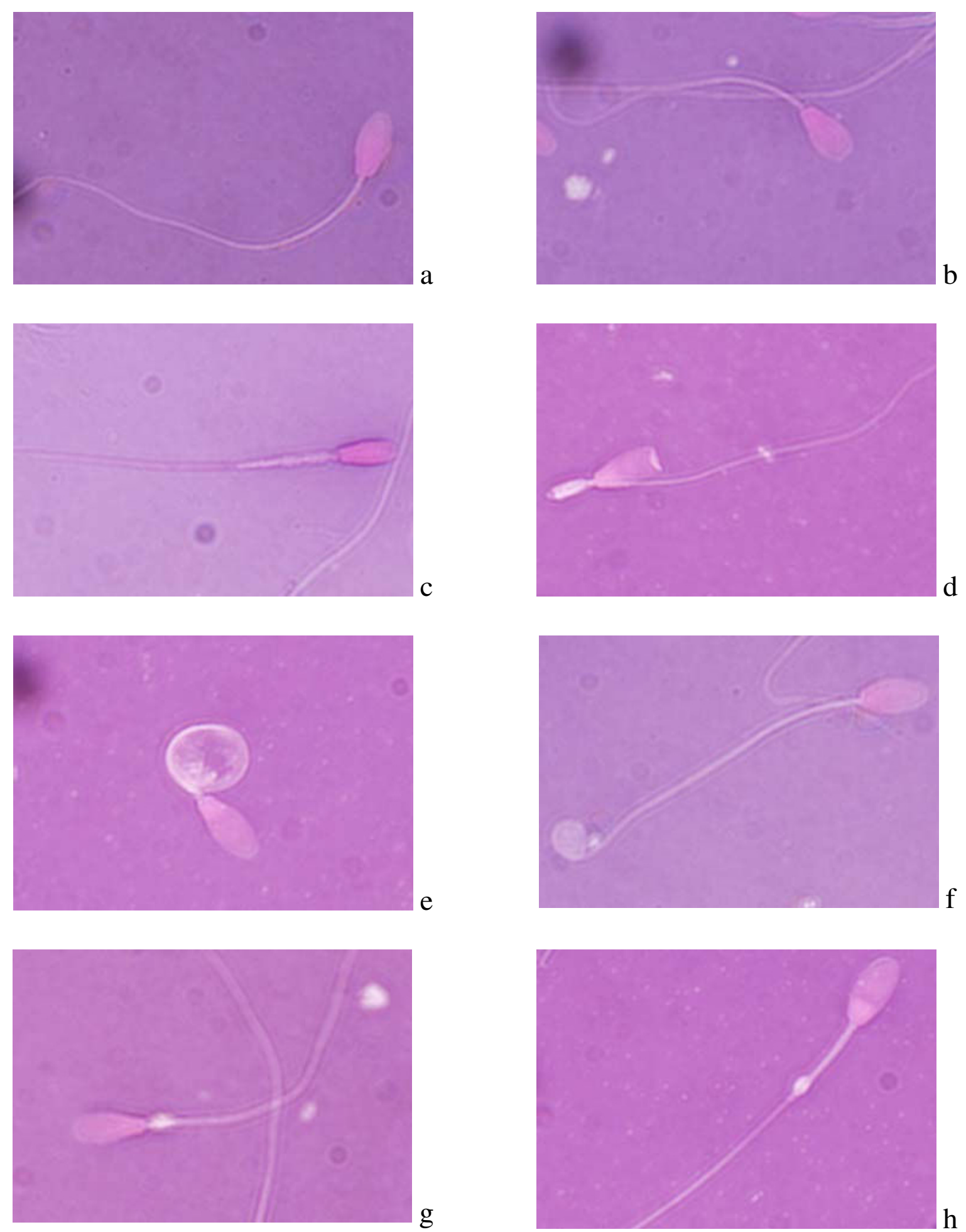

\section{Figure 2}

Light microscopy of Thai native crossbreed stallion sperm after eosin/nigrosin staining; $a$ - normal sperm; $b$ - pear shaped head; $c$ - narrow head with abnormal midpiece; $d$ - acrosomal defect with abnormal midpiece; e - coiled tail below head; $f$ - terminal coiled tail; $g$ - proximal cytoplasmic droplet and $\mathrm{h}$ - distal cytoplasmic droplet (I000x). 
Table I: Percentage of sperm morphology of Thai native crossbred (T; TI - T5) and purebred (F; FI - Standard-bred; F2 - Warmblood; F3 and F4 - Thoroughbred) stallions (mean \pm SE)

\begin{tabular}{|c|c|c|c|c|c|c|}
\hline Stallion & Normal morphology & Abnormal head & Abnormal midpiece & Abnormal tail & Proximal cytoplasmic droplet & Distal cytoplasmic droplet \\
\hline $\mathrm{TI}$ & $48.9 \pm 1.8 \mathrm{a}$ & $8.9 \pm 0.7$ a & $12.7 \pm 0.8 \mathrm{a}$ & $1.1 \pm 0.2 \mathrm{a}$ & $10.9 \pm 0.8 \mathrm{a}$ & $17.6 \pm 1.4^{a}$ \\
\hline $\mathrm{T} 2$ & $43.8 \pm 2.4^{\mathrm{a}, \mathrm{c}}$ & $14.2 \pm 1.5 b$ & $29.3 \pm 1.6 b, c$ & $\mathrm{I} .8 \pm 0.4 \mathrm{a}, \mathrm{b}$ & $8.2 \pm 1.1 \mathrm{a}, \mathrm{b}$ & $2.9 \pm 0.5 b$ \\
\hline T3 & $60.8 \pm 2.7^{b}$ & $\mathrm{II} .5 \pm \mathrm{I} .4^{\mathrm{a}, \mathrm{b}}$ & $16.2 \pm 1.6^{\mathrm{a}, \mathrm{c}}$ & $1.4 \pm 0.3 \mathrm{a}$ & $4.9 \pm 1.2 \mathrm{~b}, \mathrm{c}$ & $5.2 \pm 1.1$ b,c \\
\hline $\mathrm{T} 4$ & $38.3 \pm 2.7 c$ & $9.2 \pm 1.1 \mathrm{a}$ & $10.3 \pm 0.8 \mathrm{a}$ & $2.6 \pm 0.5 b, c$ & $28.9 \pm 2.2 \mathrm{~d}$ & $10.6 \pm 1.7 \mathrm{~d}$ \\
\hline T5 & $58.3 \pm 2.2 b$ & $9.1 \pm 1.4 \mathrm{a}$ & $19.8 \pm 1.6 \mathrm{a}$ & $1.6 \pm 0.3 \mathrm{a}, \mathrm{c}$ & $3.3 \pm 0.5^{c}$ & $7.9 \pm I .1 \mathrm{c}, \mathrm{d}$ \\
\hline $\begin{array}{l}\text { Mean T } \\
\text { (range) }\end{array}$ & $\begin{array}{c}49.7 \pm 1.3 \\
(19-75)\end{array}$ & $\begin{array}{c}10.2 \pm 0.5 * \\
\quad(2-33)\end{array}$ & $\begin{array}{c}16.5 \pm 0.8 * \\
\quad(3-4 I)\end{array}$ & $\begin{array}{c}1.6 \pm 0.1 * \\
(0-7)\end{array}$ & $\begin{array}{l}11.4 \pm 1.0 * \\
(0-42)\end{array}$ & $\begin{array}{c}10.5 \pm 0.8 * \\
(0-36)\end{array}$ \\
\hline $\mathrm{FI}$ & $40.1 \pm 3.6$ a & $13.8 \pm 1.3 \mathrm{a}$ & $31.6 \pm 3.4^{\mathrm{a}, \mathrm{b}}$ & $5.4 \pm 1.3 \mathrm{a}$ & $3.5 \pm 0.8 \mathrm{a}$ & $5.5 \pm 2.0$ \\
\hline F2 & $61.5 \pm 2.7^{b}$ & $10.2 \pm 2.1 \mathrm{a}$ & $14.3 \pm 2.5 \mathrm{a}$ & $2.7 \pm 1.0 \mathrm{~b}$ & $5.7 \pm 1.2 \mathrm{a}, \mathrm{b}$ & $5.5 \pm 2.1$ \\
\hline F3 & $35.9 \pm 3.9$ a & $17.3 \pm 2.8 b$ & $29.9 \pm 3.2 b$ & $0.3 \pm 0.2 c$ & $9.3 \pm 2.0 \mathrm{~b}$ & $7.4 \pm 1.5$ \\
\hline F4 & $58.0 \pm 5.1 \mathrm{~b}$ & $11.7 \pm 1.6^{a}$ & $17.3 \pm 2.8$ a & $4.4 \pm 1.1 \mathrm{a}, \mathrm{b}$ & $3.9 \pm 0.8 \mathrm{a}, \mathrm{b}$ & $4.7 \pm 1.3$ \\
\hline $\begin{array}{l}\text { Mean F } \\
\text { (range) }\end{array}$ & $\begin{array}{c}48.1 \pm 2.8 \\
(21-72)\end{array}$ & $\begin{array}{c}13.4 \pm 1.1 \\
(4-23)\end{array}$ & $\begin{array}{c}23.9 \pm 2.1 \\
(9-43)\end{array}$ & $\begin{array}{c}3.3 \pm 0.6 \\
(0-13)\end{array}$ & $\begin{array}{c}5.5 \pm 0.7 \\
(1-17)\end{array}$ & $\begin{array}{c}5.8 \pm 0.9 \\
(0-16)\end{array}$ \\
\hline
\end{tabular}

Significant differences $(P<0.05)$ within $T$ or $F$ are indicated by different letters $(a, b, c, d)$.

Significant differences $(P<0.05)$ between $\mathrm{T}$ and $\mathrm{F}$ are indicated by $*$ in superscript

and F stallions, respectively, which closely matches the $50 \%$ value that is considered a "normal" average for stallions [8]. Our finding is consistent with the $43.4 \%$ morphologically normal sperm with acceptable fertility [6], but lower than the value for fertile stallions $(75.5 \%)$ reported by Pesch et al. [7]. For morphologically abnormal sperm, high numbers of sperm presented with an abnormal midpiece in both $\mathrm{T}(16.5 \%)$ and $\mathrm{F}$ stallions (23.9\%). A high proportion of sperm with midpiece abnormalities $(25.3 \%)$ has also been reported by Voss et al. [32]. However, in this study, the stallions nonetheless achieved acceptable pregnancy rates of 62.5 to $91.7 \%$ [32]. One reason why the sperm specimens may have had abnormal midpiece morphology may have been due to a response to environmental insults as seen in bull scrotal insulation studies $[33,34]$. In addition to impaired epididymal function, insults to spermatocytes or spermatids are also known to result in an increase in cytoplasmic droplet concentration in bull sperm samples [33]. Our study found higher percentages of both proximal and distal cytoplasmic droplets in T stallions than in F stallions. However, these types of abnormality may [7,35] or may not $[32,36]$ affect stallion fertility. A greater impact of sperm abnormality on fertility could be caused by an abnormal head, especially a detached acrosome, as well as by a breakdown in the structural integrity of the plasma membrane and other important organelles. The latter could be identified under transmission electron microscopy [7,37].

All stallions had more than one billion morphologically normal, progressively motile sperm per ejaculate. On this basis, it might be assumed that all the T stallions were fer- tile, and that they were of comparable fertility to the proven-fertile F stallions. However, their actual fertility or pregnancy rate was not tested in this study.

The morphometric characters of normal sperm heads were significantly different among individual $\mathrm{T}$ or F stallions, and between T and F stallions. Differences in sperm head size within breed have been reported in both Warmblood [14] and Spanish thoroughbred stallions [15]. Similarly, differences between breeds have been observed in Arabian, Warm-blood, Thoroughbred and Morgan stallions [14]. The results of this study confirm that there is significant variation in normal sperm head characteristics both within and between various breeds of stallions, including the Thai native crossbred. In general, sperm in the $\mathrm{T}$ group were larger and rounder than those in the $\mathrm{F}$ group were. This may render $\mathrm{T}$ sperm more sensitive to certain types of extenders that are commonly employed in cooled storage semen [38]. The cooling rate for stallion sperm can affect sperm motility during storage $[39,40]$. Sperm of different sizes may undergo different cooling rates during a single procedure. Other researchers have also found that the 'smaller' and 'more elongated' the sperm specimen, the better the sperm's cryoresistance [12]. Thus, sperm head size or shape may be an aspect to consider as part of efforts to improve cooled storage and cryopreservation protocols.

Compared to previous studies in which the Harris' hematoxylin technique was also used, almost all the morphometric parameters of $F$ sperm heads in this study were higher than those of both sub-fertile stallions of unclassified breeds [9] and Spanish Thoroughbred stallions [28]. 
Table 2: Normal sperm head morphometry of Thai native crossbred (T; TI - T5) and purebred (F; FI - Standardbred; F2 Warmblood; F3 and F4 - Thoroughbred) stallions (mean \pm SE)

\begin{tabular}{|c|c|c|c|c|c|c|c|c|c|}
\hline Stallion & Length $(\mu \mathrm{m})$ & Width $(\mu \mathrm{m})$ & $\begin{array}{c}\text { Elongation } \\
(\%)\end{array}$ & $\begin{array}{l}\text { Perimeter } \\
(\mu \mathrm{m})\end{array}$ & Area $\left(\mu \mathrm{m}^{2}\right)$ & Ellipticity & Sfl & Sf2 & Sf3 \\
\hline TI & $6.24 \pm 0.03^{a}$ & $2.99 \pm 0.02^{\mathrm{a}}$ & $\begin{array}{l}0.35 \pm \\
0.002^{\mathrm{a}}\end{array}$ & $\begin{array}{c}15.98 \pm \\
0.04^{\mathrm{a}}\end{array}$ & $\begin{array}{c}15.88 \pm \\
0.09 \mathrm{a}, \mathrm{b}\end{array}$ & $2.09 \pm 0.0 \mathrm{I}^{\mathrm{a}}$ & $\begin{array}{l}0.78 \pm \\
0.002^{\mathrm{a}}\end{array}$ & $\begin{array}{l}1.63 \pm \\
0.006^{\mathrm{a}}\end{array}$ & $\begin{array}{l}0.92 \pm \\
0.004^{a}\end{array}$ \\
\hline $\mathrm{T} 2$ & $6.07 \pm 0.02^{b}$ & $3.19 \pm 0.02^{b}$ & $\begin{array}{l}0.31 \pm \\
0.003^{b}\end{array}$ & $\begin{array}{c}15.73 \pm \\
0.04^{b}\end{array}$ & $\begin{array}{c}16.23 \pm \\
0.09 \mathrm{~b}\end{array}$ & $1.90 \pm 0.0 \mathrm{I}^{\mathrm{b}}$ & $\begin{array}{l}0.82 \pm \\
0.002^{b}\end{array}$ & $\begin{array}{l}1.57 \pm \\
0.007 b\end{array}$ & $\begin{array}{l}0.94 \pm \\
0.003^{b}\end{array}$ \\
\hline T3 & $6.33 \pm 0.02^{c}$ & $3.19 \pm 0.0 \mathrm{I}^{\mathrm{b}}$ & $\begin{array}{l}0.33 \pm \\
0.002^{c}\end{array}$ & $\begin{array}{c}16.10 \pm \\
0.04^{\mathrm{a}}\end{array}$ & $\begin{array}{c}16.67 \pm \\
0.08 \mathrm{c}\end{array}$ & $\mathrm{I} .98 \pm 0.0 \mathrm{I}^{\mathrm{c}}$ & $\begin{array}{l}0.81 \pm \\
0.00 I^{c}\end{array}$ & $\begin{array}{l}1.60 \pm \\
0.005^{c}\end{array}$ & $\begin{array}{l}0.95 \pm \\
0.002^{b}\end{array}$ \\
\hline T4 & $\begin{array}{l}6.18 \pm \\
0.02^{\mathrm{ab}}\end{array}$ & $3.11 \pm 0.02 c$ & $\begin{array}{l}0.33 \pm \\
0.003 c\end{array}$ & $\begin{array}{c}15.76 \pm \\
0.04 b\end{array}$ & $\begin{array}{c}15.90 \pm \\
0.09 \mathrm{a}, \mathrm{b}\end{array}$ & $1.99 \pm 0.01 \mathrm{c}$ & $\begin{array}{l}0.80 \pm \\
0.002^{c}\end{array}$ & $\begin{array}{c}1.60 \pm \\
0.008^{b, c}\end{array}$ & $\begin{array}{l}0.95 \pm \\
0.004 b\end{array}$ \\
\hline T5 & $6.18 \pm 0.02^{\mathrm{a}}$ & $3.08 \pm 0.01 \mathrm{cc}$ & $\begin{array}{l}0.33 \pm \\
0.002 c\end{array}$ & $\begin{array}{c}|5.7| \pm \\
0.03^{b}\end{array}$ & $\begin{array}{c}15.77 \pm \\
0.07 \mathrm{a}\end{array}$ & $2.02 \pm 0.01 \mathrm{c}$ & $\begin{array}{l}0.80 \pm \\
0.002^{c}\end{array}$ & $\begin{array}{c}1.61 \pm \\
0.005^{a, c}\end{array}$ & $\begin{array}{l}0.95 \pm \\
0.002^{b}\end{array}$ \\
\hline Mean $\mathrm{T}$ & $6.22 \pm 0.01 *$ & $3.09 \pm 0.0^{*}$ & $\begin{array}{l}0.34 \pm \\
0.001^{*}\end{array}$ & $\begin{array}{c}15.88 \pm \\
0.02^{*}\end{array}$ & $\begin{array}{c}16.09 \pm \\
0.03^{*}\end{array}$ & $\begin{array}{l}2.01 \pm \\
0.005^{*}\end{array}$ & $\begin{array}{l}0.80 \pm \\
0.001^{*}\end{array}$ & $\begin{array}{l}1.61 \pm \\
0.003^{*}\end{array}$ & $\begin{array}{l}0.94 \pm \\
0.002^{*}\end{array}$ \\
\hline$\%$ CV $(\mathrm{T})$ & 4.5 & 6.2 & 8.5 & 3.3 & 6.6 & 6.5 & 3.3 & 4.6 & 4.2 \\
\hline $\begin{array}{r}\text { Percentile } \\
25 / 75\end{array}$ & $6.00 / 6.40$ & $2.90 / 3.20$ & $0.31 / 0.35$ & $15.60 / 16.20$ & $15.40 / 16.80$ & $1.94 / 2.10$ & $0.79 / 0.82$ & $1.56 / 1.66$ & $0.92 / 0.97$ \\
\hline $\mathrm{FI}$ & $5.94 \pm 0.02^{\mathrm{a}}$ & $2.99 \pm 0.0 \mathrm{I}^{\mathrm{a}}$ & $\begin{array}{l}0.33 \pm \\
0.002^{\mathrm{a}}\end{array}$ & $\begin{array}{c}15.14 \pm \\
0.03^{\mathrm{a}}\end{array}$ & $\begin{array}{c}14.83 \pm \\
0.07^{\mathrm{a}}\end{array}$ & $1.99 \pm 0.07 a$ & $\begin{array}{l}0.81 \pm \\
\left.0.00\right|^{a}\end{array}$ & $\begin{array}{l}1.62 \pm \\
0.004^{a}\end{array}$ & $\begin{array}{l}0.94 \pm \\
0.002^{\mathrm{a}}\end{array}$ \\
\hline F2 & $5.98 \pm 0.0 \mathrm{I}^{\mathrm{a}}$ & $2.92 \pm 0.0 \mathrm{I}^{\mathrm{b}}$ & $\begin{array}{l}0.34 \pm \\
0.002^{b}\end{array}$ & $\begin{array}{c}14.89 \pm \\
0.03^{b}\end{array}$ & $\begin{array}{c}13.97 \pm \\
0.05 b\end{array}$ & $2.06 \pm 0.0 \mathrm{I}^{\mathrm{b}}$ & $\begin{array}{l}0.79 \pm \\
0.002^{b}\end{array}$ & $\begin{array}{l}1.62 \pm \\
0.004 \mathrm{a}\end{array}$ & $\begin{array}{l}0.98 \pm \\
0.00 I^{b}\end{array}$ \\
\hline F3 & $6.15 \pm 0.03^{b}$ & $2.92 \pm 0.0 \mathrm{I}^{\mathrm{b}}$ & $\begin{array}{l}0.36 \pm \\
0.002^{c}\end{array}$ & $\begin{array}{c}15.24 \pm \\
0.05^{\mathrm{a}}\end{array}$ & $\begin{array}{c}|4.4| \pm \\
0.09 c\end{array}$ & $2.11 \pm 0.01 \mathrm{c}$ & $\begin{array}{l}0.78 \pm \\
0.002^{c}\end{array}$ & $\begin{array}{l}1.64 \pm \\
0.006^{b}\end{array}$ & $\begin{array}{l}0.98 \pm \\
0.003^{\mathrm{bc}}\end{array}$ \\
\hline F4 & $5.85 \pm 0.0 I^{c}$ & $2.80 \pm 0.01 \mathrm{c}$ & $\begin{array}{l}0.35 \pm \\
0.001 c\end{array}$ & $\begin{array}{c}14.55 \pm \\
0.03 c\end{array}$ & $\begin{array}{c}13.20 \pm \\
0.05^{d}\end{array}$ & $2.09 \pm 0.01 \mathrm{c}$ & $\begin{array}{l}0.79 \pm \\
0.001 \mathrm{c}\end{array}$ & $\begin{array}{l}1.64 \pm \\
0.004 b\end{array}$ & $\begin{array}{l}0.98 \pm \\
0.002^{c}\end{array}$ \\
\hline Mean F & $5.94 \pm 0.08$ & $2.89 \pm 0.01$ & $0.35 \pm 0.001$ & $14.88 \pm 0.02$ & $13.90 \pm 0.04$ & $2.06 \pm 0.004$ & $0.79 \pm 0.001$ & $1.63 \pm 0.002$ & $0.97 \pm 0.001$ \\
\hline \% CV (F) & 5 & 6.5 & 8.8 & 4 & 8.5 & 6.8 & 3.4 & 4.7 & 3.5 \\
\hline $\begin{array}{r}\text { Percentile } \\
25 / 75\end{array}$ & $5.70 / 6.20$ & $2.80 / 3.10$ & $0.33 / 0.36$ & $14.50 / 15.20$ & $13.10 / 14.70$ & $1.97 / 2.14$ & $0.77 / 0.81$ & $1.58 / 1.68$ & $0.95 / 0.99$ \\
\hline
\end{tabular}

Significant differences $(P<0.05)$ within $T$ or $F$ are indicated by different letters $(a, b, c, d)$.

Significant differences $(P<0.05)$ between $T$ and $F$ are indicated by $*$ in superscript

The values showing this property were, respectively, length $(5.94 \mu \mathrm{m}, 5.77 \mu \mathrm{m}, 5.67 \mu \mathrm{m})$; width $(2.89 \mu \mathrm{m}$, $2.89 \mu \mathrm{m}, 2.85 \mu \mathrm{m})$; perimeter $(14.88 \mu \mathrm{m}, 14.59 \mu \mathrm{m}$, $15.00 \mu \mathrm{m})$ and area $\left(13.90 \mu \mathrm{m}^{2}, 12.66 \mu \mathrm{m}^{2}, 13.42 \mu \mathrm{m}^{2}\right)$. Nevertheless, some parameters in our study were lower than those for certain unclassified breeds of stallions in a different research trial [41], which reported values as follows: length $6.01 \mu \mathrm{m}$, width $2.97 \mu \mathrm{m}$, perimeter $15.64 \mu \mathrm{m}$ and area $13.48 \mu \mathrm{m}^{2}$.
Within-animal group percentage CVs for all head morphometric parameters were low for sperm in both the $\mathrm{T}$ group (from 2.6 for shape factor 1 to 7.5 for elongation) and in the F group (from 2.9 for shape factor 1 to 8.1 for elongation). This reflected a homogeneous sperm population within individuals. These results were consistent with those studies which examined unclassified breeds of stallion (from 5.8 for length and perimeter to 8.8 for area) [41], ram (from 4.36 for length to 7.33 for shape factor 1 )

Table 3: Within-animal and between-animal CV of normal sperm head morphometry in Thai native crossbred (T) and purebred (F) stallions

\begin{tabular}{|c|c|c|c|c|c|c|c|c|c|}
\hline Stallion & Length & Width & Elongation & Perimeter & Area & Ellipticity & SfI & Sf2 & Sf3 \\
\hline \multicolumn{10}{|l|}{$\mathrm{T}$} \\
\hline Within-animal CV & 4.0 & 5.4 & 7.5 & 2.9 & 5.9 & 5.6 & 2.6 & 4.3 & 3.8 \\
\hline Between-animal CV & 28.9 & 17.6 & 11.2 & 19.2 & 19.8 & 13.9 & 25.8 & 13.2 & 32.0 \\
\hline \multicolumn{10}{|l|}{$\mathrm{F}$} \\
\hline Within-animal CV & 4.8 & 5.8 & 8.1 & 3.6 & 7.2 & 6.3 & 2.9 & 4.5 & 3.2 \\
\hline Between-animal CV & 5.3 & 11.9 & 17.6 & 1.6 & 4.0 & 16.0 & 26.1 & 14.2 & 7.2 \\
\hline
\end{tabular}


[16], boar (from 2.93 for rugosity or shape factor 1 to 9.38 for elongation) [20], but lower than those of the Cynomolgus monkey (from 2.90 for shape factor 1 to 16.39 for ellipticity) [42], or alpaca (from 4.7 for shape factor 1 to 17.8 for ellipticity) [18].

Between-animal group percentage CVs were higher in the sperm of T group animals (from 11.2 for elongation to 32.0 for shape factor 3 ) than in F group stallions (from 1.6 for perimeter to 26.1 for shape factor 1). Identification of individual animals might be possible if one focuses on those parameters that have low within-animal and high between-animal CVs. The literature suggest that suitable parameters for other species might include perimeter (5.42 versus 35.45 ) and shape factor 1 (7.33 versus 36.98) for rams [16], and perimeter (2.69 versus 14.43), shape factor 1 (rugosity; 2.93 versus 26.26) and shape factor 3 (regularity; 2.45 versus 16.31) for boars [20]. Meanwhile, our study suggested that perimeter (2.9 versus 19.2), shape factor 1 (2.6 versus 25.8) and shape factor $3(3.8$ versus 32.0) for $\mathrm{T}$ and shape factor 1 (2.9 versus 26.1) for F sperm were suitable parameters. The crossbred genetic background may result in increased between-animal sperm dimensional variability as compared with purebred groups.

\section{Conclusion}

The results presented here indicate that the variability in percentages of normal and abnormal morphological characteristics of sperm in individual Thai native crossbred stallions was similar to that of purebred stallions. Furthermore, the morphometric characteristics of normal sperm heads also varied substantially between stallions, with the sperm heads of Thai native crossbred stallions being larger and rounder than those of purebred stallions. Perimeter, shape factor 1 and shape factor 3 were identified as parameters that could potentially be used as a means of identifying individual $\mathrm{T}$ stallions.

\section{Competing interests}

The authors declare that they have no competing interests.

\section{Acknowledgements}

We would like to thank Assistant Professor Dr. Pariwat Poolperm for his critical comments and edits to this manuscript. We would like to thank the Department of Veterinary and Remount, Royal Thai Army, Kanchanaburi province and the Thai Horse Club, Saraburi province, for their management of the experimental animals. We also would like to thank Ms Sudarat Amornsak and Ms Piyawan Suthanmapinanh for their assistance with equipment and logistics. This work was supported by the Kasetsart University Research and Development Institute, and by the Center for Agricultural Biotechnology, Kasetsart University.

\section{References}

I. Rodriguez-Martinez $\mathrm{H}$ : Can we increase the estimative value of semen assessment? Reprod Domest Anim 2006, 4 I (suppl 2):2-I0.
2. Lewis SE: Is sperm evaluation useful in predicting human fertility? Reproduction 2007, I34:3 I-40.

3. Petrunkina AM, Waberski D, Günzel-Apel AR, Töpfer-Petersen E: Determinants of sperm quality and fertility in domestic species. Reproduction 2007, 134:3-17.

4. Turner RM: Current techniques for evaluation of stallion fertility. Clin Tech Equine Pract 2005, 4:257-268.

5. Brito LFC: Evaluation of stallion sperm morphology. Clin Tech Equine Pract 2007, 6:249-264.

6. Neild DM, Chaves MG, Flores M, Miragaya MH, Gonzalez E, Agüero $A$ : The HOS test and its relationship to fertility in the stallion. Andrologia 2000, 32:35 I-355.

7. Pesch S, Bostedt H, Failing K, Bergmann M: Advanced fertility diagnosis in stallion semen using transmission electron microscopy. Anim Reprod Sci 2006, 91 :285-298.

8. Card C: Cellular associations and the differential spermiogram: making sense of stallion sperml morphology. Theriogenology 2005, 64:558-567.

9. Casey PJ, Gravance CG, Davis RO, Chabot DD, Liu IK: Morphometric differences in sperm head dimensions of fertile and subfertile stallions. Theriogenology 1997, 47:575-582.

10. Hirai M, Boersma A, Hoeflich A, Wolf E, Foll J, Aumüller TR, Braun J: Objectively measured sperm motility and sperm head morphometry in boars (Sus scrofa): relation to fertility and seminal plasma growth factors. J Androl 200I, 22: 104-I I0.

II. Peña FJ, Saravia F, García-Herreros M, Núñez-martínez I, Tapia JA, Johannisson A, Wallgren M, Rodríguez-Martínez $\mathrm{H}$ : Identification of sperm morphometric subpopulations in two different portions of the boar ejaculate and its relation to postthaw quality. J Androl 2005, 26:716-723.

12. Esteso MC, Soler AJ, Fernández-Santos MR, Quintero-Moreno AA, Garde J: Functional significance of the sperm head morphometric size and shape for determining freezability in iberian red deer (Cervus elaphus hispanicus) epididymal sperm samples. J Androl 2006, 27:662-670.

13. Núñez-Martínez I, Moran JM, Peña FJ: Sperm indexes obtained using computer-assisted morphometry provide a forecast of the freezability of canine sperm. Int J Androl 2007, 30:182-189.

14. Ball BA, Mohammed HO: Morphometry of stallion sperm by computer-assisted image analysis. Theriogenology 1995, 44:367-377.

15. Hidalgo M, Rodríguez I, Dorado J, Soler C: Morphometric classification of Spanish thoroughbred stallion sperm heads. Anim Reprod Sci 2008, I03:374-378.

16. Sancho M, Pérez-Sánchez F, Tablado L, de Monserrat Jl, Soler C: Computer assisted morphometric analysis of ram sperm heads: evaluation of different fixative techniques. Theriogenology 1998, 50:27-37.

17. Boersma AA, Braun J, Stolla R: Influence of random factors and two different staining procedures on computer assisted sperm head morphometry in bulls. Reprod Domest Anim 1999, 34:77-82.

18. Buendía P, Soler C, Paolicchi F, Gago G, Urquieta B, Pérez-Sánchez F, Bustos-Obregón E: Morphometric characterization and classification of alpaca sperm heads using the sperm-class analyzer computer-assisted system. Theriogenology 2002, 57:1207-1218.

19. Soler C, Gadea B, Soler AJ, Fernández-Santos MR, Esteso MC, Núñez J, Moreira PN, Núñez M, Gutiérrez R, Sancho M, Garde JJ: Comparison of three different staining methods for the assessment of epididymal red deer sperm morphometry by computerized analysis with ISAS. Theriogenology 2005, 64: I 236-I 243.

20. García-Herreros M, Aparicio IM, Barón FJ, García-Marín LJ, Gil MC: Standardization of sample preparation, staining and sampling methods for automated sperm head morphometry analysis of boar sperm. Int J Androl 2006, 29:553-563.

21. Dahlbom M, Andersson M, Vierula M, Alanko M: Morphometry of normal and teratozoospermic canine sperm heads using an image analyzer: work in progress. Theriogenology 1997, 48:687-698.

22. Saravia F, Núñez-Martínez I, Morán JM, Soler C, Muriel A, RodríguezMartínez H, Peña FJ: Differences in boar sperm head shape and dimensions recorded by computer-assisted sperm morphometry are not related to chromatin integrity. Theriogenology 2007, 68:196-203. 
23. Aggarwal RA, Ahlawat SP, Kumar Y, Panwar PS, Singh K, Bhargava M: Biometry of frozen-thawed sperm from eight breeds of Indian buffaloes (Bubalus bubalis). Theriogenology 2007, 68:682-686.

24. Ward Pl: Intraspecific variation in sperm size characters. Heredity 1998, 80:655-659.

25. Panasophonkul S, Lohachit C, Sirivaidyapong S: Postpartum Ovarian Activity and Serum Estradiol-1 7 beta Level in Thai Crossbred Native Mares. Reprod Domest Anim 2007, 42:6-10.

26. Hancock JL, Trevan DJ: The acrosome and post-nuclear cap of bull sperm. Microsc Soc 1957, 76:77-83.

27. Dowsett KF, Osborne HG, Pattie WA: Morphological characteristics of stallion sperm. Theriogenology 1984, 22:463-472.

28. Hidalgo M, Rodrý'guez I, Dorado J, Soler C: Effect of sample size and staining methods on stallion sperm morphometry by the Sperm Class Analyzer. Vet Med-Czech 2005, 50:24-32.

29. Dowsett KF, Knott LM: The influence of age and breed on stallion semen. Theriogenology 1996, 46:397-4I2.

30. Pickett BW: Reproductive evaluation of the stallion. In Equine Reproduction Edited by: McKinnon AO, Voss JL. Philadelphia, Lea \& Febiger; 1993:755-768.

31. Kavak A, Lundeheim N, Aidnik M, Einarsson S: Sperm morphology in Estonian and Tori breed stallions. Acta Vet Scand 2004, 45:II-I8.

32. Voss JL, Pickett BW, Squires EL: Stallion sperml morphology and motility and their relationships to fertility. J Am Vet Med Assoc I 98I, I 78:287-289.

33. Brito LF, Silva AE, Barbosa RT, et al.: Effects of scrotal insulation on sperm production, semen quality, and testicular echotexture in Bos indicus and Bos indicus $\times$ Bos taurus bulls. Anim Reprod Sci 2003, 79: I-I5.

34. Barth AD, Oko RJ: Abnormal Morphology of Bovine Sperm lowa State University Press; 1989.

35. Jasko $\mathrm{D}$, Lein $\mathrm{DH}$, Foote $\mathrm{RH}$ : Determination of the relationship between sperm morphologic classifications and fertility in stallions: 66 cases (1987-1988). J Am Vet Med Assoc 1990, 197:389-394.

36. Love CC, Varner DD, Thompson JA: Intra and inter-stallion variation in sperm morphology and their relationship with fertility. J Reprod Fertil Suppl 2000, 56:93-100.

37. Veeramachaneni DN, Moeller CL, Sawyer HR: Sperm morphology in stallions: ultrastructure as a functional and diagnostic tool. Vet Clin North Am Equine Pract 2006, 22:683-692.

38. Phetudomsinsuk K, Sirinarumitr K, Choothesa $A$, Suthanmapinunt $P$, Kornkaewrat K, Laikul A, Amornsak S, Pinyopummin A: Effects of Extenders and Glutamine on Semen Characteristics of Thai Native Crossbred and Full Size Purebred Horses after Cooled Storage. Kasetsart J (Nat Sci) 2008, 42:473-484.

39. Varner DD, Blanchard TL, Love CL, Garcia MC, Kenney RM: Effects of cooling rate and storage temperature on equine sperml motility parameters. Theriogenology 1988, 29: 1043-1054.

40. Moran DM, Jasko DJ, Squires EL, Amann RP: Determination of temperature and cooling rate which induce cold shock in stallion sperm. Theriogenology 1992, 38:999-1012.

4I. Gravance CG, Champion Z, Liu IK, Casey PJ: Sperm head morphometry analysis of ejaculate and dismount stallion semen samples. Anim Reprod Sci 1997, 47:149-155.

42. Gago C, Pérez-Sánchez F, Yeung CH, Tablado L, Cooper TG, Soler C: Morphological characterization of ejaculated cynomolgus monkey (Macaca fascicularis) sperm. Am J Primatol 1999, 47:105-115.

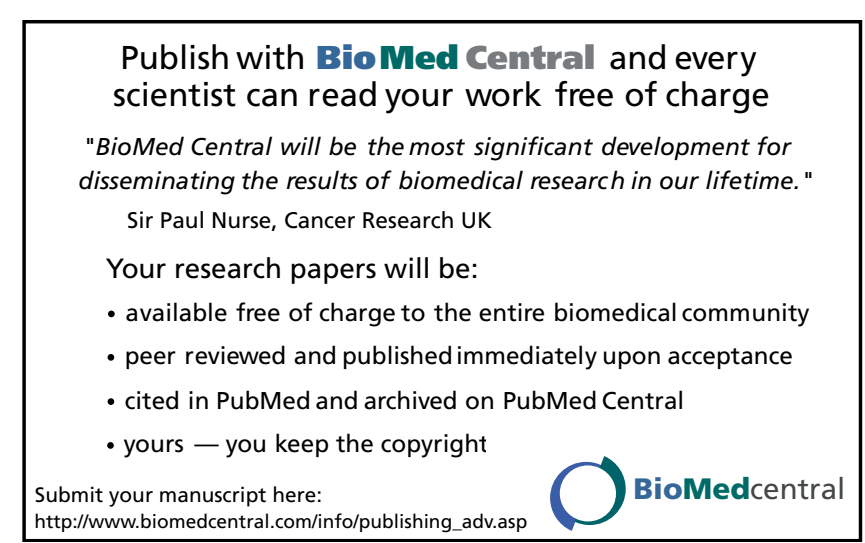

